\title{
Country, age, and gender differences in the prevalence of screen-based behaviour and family-related factors among school-aged children
}

\author{
Jan Pavelka ${ }^{1, *}$, Daniela Husarova ${ }^{2}$, Anna Sevcikova ${ }^{3}$, and Andrea Madarasova Geckova ${ }^{1,2}$ \\ ${ }^{I}$ Faculty of Physical Culture, Palacký University Olomouc, Olomouc, Czech Republic; ${ }^{2}$ Faculty of Medicine, Pavol

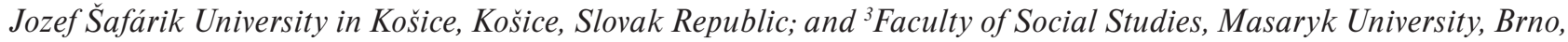 \\ Czech Republic
}

Copyright: (C) 2016 J. Pavelka et al. This is an open access article licensed under the Creative Commons Attribution License (http://creativecommons.org/licenses/by/4.0/).

\begin{abstract}
Background: New information and communication technologies have become an important part of adolescents' everyday lives. However, the sedentary behaviour of young people in Central Europe has become more similar to that found in Western European countries. This study can provide baseline data for a future comparison and investigation of lifestyle and health behaviours in this region in the future. Objective: The aim of this study is to assess country, age, and gender differences in the prevalence of sedentary behaviour activities and family-related factors among schoolaged children. Methods: Using the methodology of the Health Behaviour in School-aged Children (HBSC) study was performed in 2013, collecting data from 11- and 15-year-old Slovak $(n=488)$ and Czech $(n=418)$ children. The data was explored using $\chi^{2}$ tests to determine statistical significance. Results: Two-thirds of the respondents watch television or use a computer for at least two hours a day. The older children (older vs. younger: $73.6 \%$ vs. $53.9 \%, \chi^{2}=35.6$, $p<.001)$ spent excessive amounts of time watching television. More than half of the children have a television (51.9\%) or a computer $(73.0 \%)$ in their bedroom. More than half of their parents rarely or never apply rules about how long they can watch TV (63.9\%) or time spent on the computer (55.5\%). The Slovak children reported watching television together with their parents every day significantly more frequently than their Czech peers (Slovak vs. Czech children $31.0 \%$ vs. $\left.18.7 \%, \chi^{2}=17.9, p<.001\right)$. Conclusions: The prevalence of screen-based behaviour is relatively high, as is screen time spent together with parents, especially among the Slovak children. Moreover, many children reported that their parents rarely or never applied rules about the length and content of their television watching or time spent on the computer.
\end{abstract}

Keywords: screen-based activities, family-shared activities, parental rules

\section{Introduction}

There is a rapidly growing number of research studies in the field of "sedentary behaviour" in young people and adults as a result of concern about the amount of time people spend sitting (Biddle, O'Connell, \& Braithwaite, 2011). Therefore, this paper can contribute to understanding the lives of Central European people because the political transitions in Central Europe, including the Czech Republic and Slovakia, in 1989 had a strong influence on people's lifestyle in these countries. The political change was associated with the

\footnotetext{
* Address for correspondence: Jan Pavelka, Institute of Active Lifestyle, Faculty of Physical Culture, Palacký University Olomouc, třída Míru 117, 77111 Olomouc, Czech Republic. E-mail: jan.pavelka@upol.cz
}

creation of new social values and preferences and recent trends have also shown significant technological development in this region (Hamar, Biddle, Soós, Takács, \& Huszár, 2009; Soos et al., 2012). Generally, country differences in screen-based activities in the Central European region, with its common historical experience, are usually small (Guthold, Cowan, Autenrieth, Kann, \& Riley, 2010; Sigmundová, Sigmund, Kalman, \& Hamrik, 2013; Torsheim et al., 2010). However, this study can provide baseline data for a comparison and investigation of lifestyle and health behaviours in this region in the future (Brindova, Veselska, et al., 2014; Bucksch, Inchley, Hamrik, Finne, \& Kolip, 2014).

According to the findings of the international Health Behaviour in School-aged Children (HBSC) study, around $58 \%$ of 11 - and 15 -year-old adolescents watch television for two or more hours on weekdays, 
and the prevalence increases with age (Inchley et al., 2016). Furthermore, the results of the European Union EU Kids Online II survey 2011 (Livingstone, Haddon, Görzig, \& Ólafsson, 2011) indicate that 9 to 16 year old children use the internet for almost an hour and a half every day, and this figure increases steeply with age. These results are not in line with the recommendations of professional health organizations, including the Canadian Pediatric Society (CPS) and the American Academy of Pediatrics (AAP), which recommend that children should not spend more than two hours per day on screen-related sedentary activities (CPS, 1999; Strasburger, Jordan, \& Donnerstein, 2010).

Both "old" media (television, movies, and magazines) and "new" media (internet, video/computer games, and cell phones) can have an impact on virtually every health concern that practitioners and parents have about young people, including aggressive behaviour, risky sexual behaviour, substance use, and disordered eating (Murray, 2008) or physical and psychological problems (Brindova, Veselska, et al., 2014). It is becoming clear that the total time spent on sedentary behaviour and the length and number of the sedentary bouts are important factors for health in adolescents (Ekelund et al., 2006).

In children, the influence of home and familial characteristics on sedentary behaviour patterns has been a key area of research (Brindova, Pavelka, et al., 2014), particularly regarding the impact of electronic media [television (TV), computers (PCs), and video game consoles] in the bedroom. Access to media devices in the bedroom is growing rapidly and correlates with the time spent watching TV and playing video games (Granich, Rosenberg, Knuiman, \& Timperio, 2010). The presence of a TV and PC in the bedroom is also associated with additional total screen time. This result is consistent with previous studies, which used both subjective and objective measures of screen time behaviours (Rosenberg et al., 2010).

Parents seem to have an important role in regulating the total amount of screen-based activities in children. The presence of parental rules focused on limiting screen time appeared to be one of the key factors that influence the amount of time spent on screen-based behaviour in youth (He, Harris, Piché, \& Beynon, 2009; Te Velde et al., 2011; Vandewater, Park, Huang, \& Wartella, 2005). Moreover, rules regarding TV and PC use can have an impact on other activities that children participate in. TV time rules were indeed related to lower levels of viewing. But TV programme rules predicted more parental presence during viewing (Vandewater et al., 2005). Furthermore, the children of parents with screen-based activity rules tended to spend more time playing outdoors (Tandon et al., 2012).

The economic developments in the Czech Republic and Slovakia since the Velvet Revolution in 1989 have brought many positive and negative changes in lifestyle (Sigmundová et al., 2013). In the Czech Republic and Slovakia, the prevalence and patterns of screen-based activities have changed rapidly. The EU Kids Online report of 2011 (Livingstone et al., 2011) suggested that both countries were behind in terms of internet connectivity in comparison with other European countries. However, since that time this area has developed rapidly, which might have caused some changes in the amount of time spent on screen-based activities.

The aim of this study is to investigate country, age, and gender differences in the prevalence of screenbased activities and family-related factors (availability of a TV or PC in the bedroom, parental rules on time spent watching TV or on PC use, and the content of such TV watching or PC use, and activities done together with parents) among Slovak and Czech children of school age.

\section{Methods}

\section{Sample and procedure}

The present survey follows the international HBSC study and its methodology is identical. The HBSC is performed in cooperation with the World Health Organization and is an international school-based study focusing on the health and health behaviour of 11-, 13-, and 15-year-old schoolchildren in their respective social environments. Our purpose was to assess the applicability of the questionnaire in 11- and 15-year-old respondents of HBSC sample.

The authors performed the survey in November 2013 in the Czech Republic and Slovakia. It was preceded by a pilot study, the purpose of which was to administer the questionnaires and use focus groups in the two countries. The data obtained during the pilot study was used to formulate the final set of questions. A total of 16 larger and smaller primary schools were addressed. These schools were located in rural and urban areas in the Olomouc Region, Czech Republic (seven schools), and the Košice Region, Slovakia (nine schools). The variables, i.e. family structure, screen-based behaviour, and parental rules, relating to the samples are similar to those in other studies covering all regions. Therefore, the authors believe that the results concerning the relations between family-related factors and screen-based activities in Czech and Slovak adolescents can be generalized to a broader sample. The institutions in the study were selected randomly in 
order to be representative. The response rate was one hundred per cent as all the schools decided to participate in the study. The administration of the questionnaires was performed in the fifth and ninth grades by trained assistants. During the administration the teacher was not present in the classroom.

The survey was authorized by the Ethics Committee of the Faculty of Physical Culture, Palacký University Olomouc (15 May, 2013) and by the Ethics Committee of the Medical Faculty, Pavol Jozef Šafárik University in Košice (18 June, 2012). All the Czech schools participating in the study had a general permission granted by all parents at the beginning of the school year. The Slovak parents were informed about the survey by the school administration and had an opportunity to withdraw. The study was conducted on a voluntary and anonymous basis; no incentives were provided in return for participation.

\section{Measures}

The study focused on two types of screen-based activities. These were watching TV and playing on a PC, both of which were measured by means of two separate items. TV viewing was assessed using the following question: "About how many hours a day do you usually watch TV (including videos) in your free time?" Playing PC games was assessed by the following question: "About how many hours a day do you play PC games or TV games (PlayStation, Xbox, GameCube, etc.) in your free time?" For all the questions, the same set of nine responses was provided for both weekdays and weekends. These were "none at all", "about half an hour a day", "about one hour a day", "about two hours a day", "about three hours a day", "about four hours a day", "about five hours a day", "about six hours a day", and "about seven or more hours a day" (Torsheim et al., 2010).

The study used the guidelines of the AAP (2001), according to which two categories of excessive and non-excessive screen-based activities were created these groups included those who spent less than two hours a day and those who spent two or more hours per day doing screen-based activities.

The study also focused on whether the respondents had electronic devices in the room where they sleep and study. The devices included the following: "radio/ CD player", "TV", "PC", "internet". Each item had two response categories, i.e. "yes" or "no". The answers referred to in the statistical analyses asked about the availability of a TV and PC.

In the study, the respondents were also asked about the structure of their family. This was measured by asking the following question: "The family, where you live is... (1) a two-parent household in which neither is a step-parent (complete intact family), (2) one parent is a step-parent (complete mixed family), or (3) a singleparent household (incomplete family)."

As far as parental rules are concerned, the authors focused on restrictions related to TV or PC use. The study used separate items concerning limitations on the time and content of television programmes and PC use. The respondents were asked to indicate the extent to which selected rules were applied in their respective family environments. The following questions were used: "My parents limit the time I can spend watching TV"; "My parents limit the content of the programmes I watch on TV"; "My parents limit the time I spend playing PC games"; "My parents limit the content of my PC use". The answers were indicated on a fourpoint scale: "always", "mostly", "rarely", "never". The responses were then dichotomized into rarely and never vs. mostly and always.

Further part of the study was focused on "shared family activities". These were assessed on a scale adopted from Sweeting, West, and Richards (1998). A list of eight activities that families commonly do together was used for the assessment. The participants were supposed to indicate how often they and their family members usually did these activities together, including watching TV and videos, playing indoor games, eating a meal, going for a walk, going to places, visiting friends or relatives, playing sports, and sitting and talking about things (Loke \& Mak, 2013). The answers were indicated on a five-point scale, which included the following: "every day", "most days", "about once a week", "less often", and "never". In our study we use only one item connected to watching TV together with parents. The answers were dichotomized into the two following categories: (1) watching TV together "every day", (2) watching TV together on "most days", about "once a week", "less often", and "never".

\section{Statistical analyses}

Descriptive statistics were used for the variables that were studied. All data were analysed using IBM SPSS (Version 20 for Windows; IBM, Armonk, NY, USA). Country, gender, and age differences in the prevalence of screen-based behaviour and family-related factors (the availability of a TV or PC in the bedroom, parental rules, watching TV together with parents) were explored using $\chi^{2}$ tests. We set the significance level at $p<.05$ and applied Bonferroni correction $(p<.05 / 3)$ as well. 


\section{Results}

We obtained data from 906 adolescents in the Czech Republic (response rate: $83.2 \%$ ) and Slovakia (response rate: $74.1 \%)$. Non-response was primarily due to illness and parental non-consent regarding the participation of their children. The final sample consisted of 418 Czech ( $46.1 \%$ boys) and 488 Slovak (53.9\% boys) primary school pupils in grades five (mean age 11.0 years, standard deviation $[S D]=0.7$ ) and nine (mean age 15.0 years, $S D=0.5$ )

Country, age, and gender differences in screen-based behaviours

Two-thirds of the respondents watched TV or played PC games for at least two hours a day (Table 1). The Czech children did not differ from the Slovak children (TV/PC: $\chi^{2}=0.3 / 2.7, p=.653$ and $p=.349$, respectively); therefore, we did not consider this variable in further models. While there were no gender differences in terms of excessive time spent watching $\mathrm{TV}\left(\chi^{2}=1.6\right.$, $p=.210$ ), boys were more likely to report excessive time spent playing PC games than girls (boys vs. girls $65.4 \%$ vs. $53.7 \%, \chi^{2}=11.9, p<.001$ ). The older children spent excessive time watching TV (older vs. younger: $73.6 \%$ vs. $\left.53.9 \%, \chi^{2}=35.6, p<.001\right)$ as well as playing PC games (older vs. younger: $77.6 \%$ vs. $40.6 \%, \chi^{2}=119.9$, $p<.001)$ more often than younger children.

\section{Country, age, and gender differences in family-related factors}

Most of the adolescents reported a complete and intact $(80.1 \%)$ or a complete and mixed family $(11.7 \%)$. An incomplete family was reported by $8.2 \%$ of the respondents.

More than half of the children had a TV available in their bedroom and nearly three-quarters had a PC available in their bedroom (Table 2). On the evidence of the

Table 1

Descriptive characteristics of the sample

\begin{tabular}{|c|c|c|c|}
\hline Item & Characteristic & $n$ & $\%$ \\
\hline \multirow[t]{2}{*}{ Country } & Slovakia & 488 & 53.9 \\
\hline & Czech Republic & 418 & 46.1 \\
\hline \multirow[t]{2}{*}{ Gender } & boys & 478 & 52.8 \\
\hline & girls & 428 & 47.2 \\
\hline \multirow[t]{2}{*}{ Age (grade) } & 11 years old (5th grade) & 458 & 50.6 \\
\hline & 15 years old (9th grade) & 448 & 49.4 \\
\hline \multirow[t]{3}{*}{ Family completeness } & complete intact family & 704 & 80.1 \\
\hline & complete mixed family & 103 & 11.7 \\
\hline & incomplete family & 72 & 8.2 \\
\hline \multirow[t]{2}{*}{ TV located in bedroom } & yes & 470 & 52.6 \\
\hline & no & 424 & 47.4 \\
\hline \multirow[t]{2}{*}{ PC located in bedroom } & yes & 661 & 73.4 \\
\hline & no & 240 & 26.6 \\
\hline \multirow[t]{2}{*}{ Watching TV } & less than two hours a day & 305 & 36.0 \\
\hline & two or more hours a day & 543 & 64.0 \\
\hline \multirow[t]{2}{*}{ PC use } & less than two hours a day & 340 & 40.2 \\
\hline & two or more hours a day & 506 & 59.8 \\
\hline \multirow{2}{*}{$\begin{array}{l}\text { Parents apply rules about time spent } \\
\text { watching TV }\end{array}$} & rarely-never & 518 & 63.9 \\
\hline & every day-almost every day & 293 & 36.1 \\
\hline \multirow{2}{*}{$\begin{array}{l}\text { Parents apply rules about content of } \\
\text { TV programmes }\end{array}$} & rarely-never & 563 & 69.6 \\
\hline & every day-almost every day & 246 & 30.4 \\
\hline \multirow{2}{*}{$\begin{array}{l}\text { Parents apply rules about time spent } \\
\text { using PC }\end{array}$} & rarely-never & 446 & 55.5 \\
\hline & every day-almost every day & 357 & 44.5 \\
\hline \multirow{2}{*}{$\begin{array}{l}\text { Parents apply rules about content of } \\
\text { PC use }\end{array}$} & rarely-never & 531 & 66.8 \\
\hline & every day-almost every day & 264 & 33.2 \\
\hline \multirow[t]{2}{*}{ Watching TV together with parents } & every day & 226 & 25.3 \\
\hline & most days & 666 & 74.7 \\
\hline
\end{tabular}


Table 2

Age differences in the prevalence of screen-based behaviour and family-related factors

\begin{tabular}{|c|c|c|c|c|c|c|}
\hline \multirow[b]{2}{*}{ Item } & \multirow[b]{2}{*}{ Characteristic } & \multicolumn{2}{|c|}{5 th grade } & \multicolumn{2}{|c|}{ 9th grade } & \multirow[b]{2}{*}{$p$ value } \\
\hline & & $n$ & $\%$ & $n$ & $\%$ & \\
\hline \multirow[t]{3}{*}{ Family completeness } & complete intact family & 370 & 84.7 & 334 & 75.6 & .003 \\
\hline & complete mixed family & 39 & 8.9 & 64 & 14.5 & \\
\hline & incomplete family & 28 & 6.1 & 44 & 9.8 & \\
\hline \multirow[t]{2}{*}{ TV located in bedroom } & yes & 222 & 49.4 & 248 & 55.4 & .060 \\
\hline & no & 227 & 50.6 & 197 & 44.6 & \\
\hline \multirow[t]{2}{*}{ PC located in bedroom } & yes & 297 & 65.3 & 364 & 81.6 & .001 \\
\hline & no & 158 & 34.7 & 82 & 18.4 & \\
\hline \multirow[t]{2}{*}{ Watching TV } & less than two hours a day & 187 & 46.1 & 116 & 26.4 & $<.001$ \\
\hline & two or more hours a day & 219 & 53.9 & 324 & 73.6 & \\
\hline \multirow[t]{2}{*}{ PC use } & less than two hours a day & 241 & 59.4 & 98 & 22.4 & $<.001$ \\
\hline & two or more hours a day & 165 & 40.6 & 340 & 77.6 & \\
\hline \multirow{2}{*}{$\begin{array}{l}\text { Parents apply rules about time spent } \\
\text { watching TV }\end{array}$} & rarely-never & 167 & 44.1 & 351 & 81.3 & $<.001$ \\
\hline & every day-almost every day & 212 & 55.9 & 81 & 18.8 & \\
\hline \multirow{2}{*}{$\begin{array}{l}\text { Parents apply rules about content of } \\
\text { TV programmes }\end{array}$} & rarely-never & 184 & 49.1 & 379 & 87.3 & $<.001$ \\
\hline & every day-almost every day & 191 & 50.9 & 55 & 12.7 & \\
\hline \multirow{2}{*}{$\begin{array}{l}\text { Parents apply rules about time spent } \\
\text { using PC }\end{array}$} & rarely-never & 144 & 38.4 & 302 & 70.6 & $<.001$ \\
\hline & every day-almost every day & 231 & 61.6 & 126 & 29.4 & \\
\hline \multirow{2}{*}{$\begin{array}{l}\text { Parents apply rules about content of } \\
\text { PC use }\end{array}$} & rarely-never & 172 & 46.9 & 359 & 83.9 & $<.001$ \\
\hline & every day-almost every day & 195 & 53.1 & 69 & 16.1 & \\
\hline \multirow[t]{2}{*}{ Watching TV together with parents } & every day & 334 & 74.6 & 332 & 74.8 & .060 \\
\hline & most days & 114 & 25.4 & 112 & 25.2 & \\
\hline
\end{tabular}

children's experience, $63.9 \%$ of their parents rarely or never applied rules concerning the time spent watching TV and $69.6 \%$ rarely or never applied rules concerning the content of TV programmes. Similarly, 55.5\% of the parents rarely or never applied rules concerning the time spent using a PC and $66.8 \%$ of the children reported that their parents rarely or never applied rules about the content of their PC use. A quarter of the children reported watching TV together with their parents every day.

Older children reported a PC in their bedroom more often than younger children (older vs. younger: $81.6 \%$ vs. $\left.65.3 \%, \chi^{2}=30.8, p<.001\right)$.

Younger children reported parental rules concerning time spent watching TV (younger vs. older 55.9\% vs. $18.8 \%, \chi^{2}=121.0, p<.001$ ), TV content (younger vs. older $50.9 \%$ vs. $12.7 \%, \chi^{2}=139.2 p<.001$ ), PC use (younger vs. older $61.6 \%$ vs. $29.4 \%, \chi^{2}=83.7, p<.001$ ), and the content of PC use (younger vs. older $53.1 \%$ vs. $\left.16.1 \%, \chi^{2}=122.0, p<.001\right)$ significantly more frequently than older children (Table 3 ). No age differences were confirmed in terms of reporting having a TV in the bedroom or watching TV together with parents. With some exceptions, we did not confirm country or gender differences in family-related factors. The Slovak children reported watching TV together with their parents every day significantly more frequently than their Czech peers (Slovak vs. Czech children $31.0 \%$ vs. $\left.18.7 \%, \chi^{2}=17.9, p<.001\right)$.

\section{Discussion}

The aim of this study was to investigate the prevalence of screen-based behaviour and family-related factors among school-aged children in Slovakia and the Czech Republic and possible country, age, and gender differences.

Our study showed that more than half of the children exceeded the screen time recommended by the AAP (2001) and these findings are also consistent with other countries (Bobakova et al., 2014; Bucksch et al., 2014; Hamar et al., 2009; Soos et al., 2012). Moreover, the findings suggest that the older children had a strong tendency to spend more leisure time on screenbased activities, as well as the boys being more likely than the girls to report excessive time spent playing PC games, which is in line with prior research showing the 
Table 3

Country differences in the prevalence of screen-based behaviour and family-related factors

\begin{tabular}{|c|c|c|c|c|c|c|}
\hline \multirow[b]{2}{*}{ Item } & \multirow[b]{2}{*}{ Characteristic } & \multicolumn{2}{|c|}{ Slovakia } & \multicolumn{2}{|c|}{ Czech Republic } & \multirow[b]{2}{*}{$p$ value } \\
\hline & & $n$ & $\%$ & $n$ & $\%$ & \\
\hline \multirow[t]{3}{*}{ Family completeness } & complete intact family & 396 & 83.2 & 308 & 76.4 & \\
\hline & complete mixed family & 36 & 7.6 & 67 & 16.6 & $<.001$ \\
\hline & incomplete family & 44 & 9.2 & 28 & 6.9 & \\
\hline \multirow[t]{2}{*}{ TV located in bedroom } & yes & 249 & 51.9 & 221 & 53.4 & \\
\hline & no & 231 & 48.1 & 193 & 46.6 & .65 \\
\hline \multirow[t]{2}{*}{ PC located in bedroom } & yes & 362 & 74.6 & 299 & 71.9 & \\
\hline & no & 123 & 25.4 & 177 & 28.1 & .35 \\
\hline \multirow[t]{2}{*}{ Watching TV } & less than two hours a day & 153 & 35.0 & 150 & 36.7 & \\
\hline & two or more hours a day & 284 & 65.0 & 259 & 63.3 & $<.001$ \\
\hline \multirow[t]{2}{*}{ PC use } & less than two hours a day & 163 & 37.5 & 176 & 43.0 & \\
\hline & two or more hours a day & 272 & 62.5 & 233 & 57.0 & .01 \\
\hline \multirow{2}{*}{$\begin{array}{l}\text { Parents apply rules about time spent } \\
\text { watching TV }\end{array}$} & rarely-never & 267 & 65.4 & 251 & 62.3 & \\
\hline & every day-almost every day & 141 & 34.6 & 152 & 37.7 & .03 \\
\hline \multirow{2}{*}{$\begin{array}{l}\text { Parents apply rules about content of } \\
\text { TV programmes }\end{array}$} & rarely-never & 281 & 69.0 & 282 & 70.1 & \\
\hline & every day-almost every day & 126 & 31.0 & 120 & 29.9 & .94 \\
\hline \multirow{2}{*}{$\begin{array}{l}\text { Parents apply rules about time spent } \\
\text { using PC }\end{array}$} & rarely-never & 228 & 56.9 & 218 & 54.2 & \\
\hline & every day-almost every day & 173 & 43.1 & 184 & 45.8 & .31 \\
\hline \multirow{2}{*}{$\begin{array}{l}\text { Parents apply rules about content of } \\
\text { PC use }\end{array}$} & rarely-never & 260 & 65.2 & 271 & 68.4 & \\
\hline & every day-almost every day & 139 & 34.8 & 125 & 31.6 & .38 \\
\hline \multirow[t]{2}{*}{ Watching TV together with parents } & every day & 149 & 31.0 & 77 & 18.7 & \\
\hline & most days & 331 & 69.0 & 335 & 81.3 & $<.001$ \\
\hline
\end{tabular}

importance of media in adolescents' lives (Hamar et al., 2009; Livingstone et al., 2011; Marshall, Gorely, \& Biddle, 2006; Melkevik, Torsheim, Iannotti, \& Wold, 2010; Soos et al., 2012). Bucksch et al. (2014), for example, highlight the fact that 15 year old girls in Germany showed sharper increases in PC use than boys over time, especially for non-gaming purposes. The explanation may be that PCs have become increasingly affordable over the past decade and girls are more active in electronic communication and social media (Hamar et al., 2009).

The results from this study showed that more than half of the children had a TV and nearly three-quarters had a PC available in their bedroom. Frequent availability in children's bedrooms is supported by e.g. the Kaiser Family Foundation Study 2010 (Rideout, Foehr, \& Roberts, 2010). Gender and age differences were not indicated, with the exception of having a PC in the bedroom. However, older children reported a PC in their bedroom more often than younger children.

The high prevalence of bedroom TV and PC ownership is associated with children's excessive screen-time activities (Atkin, Corder, \& van Sluijs, 2013; Brindova, Pavelka, et al., 2014), overweight, interference with sleep (Barr-Anderson, Van Den Berg, NeumarkSztainer, \& Story, 2008), and increased exposure to advertising for unhealthy foods (Garrison, Liekweg, \& Christakis, 2011). In addition, various studies have suggested that the home environment, and in particular the presence of a TV and PC in a child's bedroom, influences children's screen-based activities (Brindova, Pavelka, et al., 2014). Similar findings have been reported in many previous studies that suggested that children with a TV in their bedroom watched more TV and had fewer rules about TV than children without a TV in their bedroom (Barr-Anderson et al., 2008; Garrison et al., 2011). A possible way to reduce screen time as a part of potentially modifiable interventions is to remove the TV and PC from the bedroom (Tandon et al., 2012).

According to our findings, more than half of the children reported that their parents rarely or even never applied rules limiting the time they spent watching TV or playing PC games and around two-thirds of them reported limiting rules about the content of TV programmes or PC use were rare. Similar findings have been reported in other European countries (De Decker, De Craemer, De Bourdeaudhuij, Wijndaele, 
\& Duvinage, 2013; Rebholz, Chinapaw, Van Stralen, Bere, \& Bringolf, 2014). While the application of these limiting rules decreases with age, gender differences were only observed in the case of PC time rules. Some other studies also indicated that parental rules were less applied when a child became older (Garmendia, Garitaonandia, Martinez, \& Casado, 2012), which might be connected with increasing needs for autonomy and independence among older adolescents (Steinberg \& Morris, 2001).

As for gender differences, girls reported this limiting rule being applied less frequently in comparison with boys, which was indicated in Salmon, Timperio, Telford, Carver, and Crawford (2012). A possible reason for this might be the fact that playing PC games and other similar PC use are more common among boys, and therefore parents apply PC time rules to them more often in comparison with girls (Yang, Helgason, Sigfusdottir, \& Kristjansson, 2012).

In addition, our findings suggest that around a quarter of the children watch TV together with their parents every day. Watching TV with parents could be a solution to the question of how to spend their unstructured leisure time (Brindova, Pavelka, et al., 2014), or in this way parents can better monitor which TV programmes their children watch (Beets, Cardinal, \& Alderman, 2010; Hersey, McDivitt, \& Heitzler, 2006; Rebholz et al., 2014; Valkenburg, Krcmar, Peeters, \& Marseille, 1999). This is the only kind of behaviour for which we found country differences between the Czech and Slovak adolescents. The Slovak children reported watching TV together with their parents more frequently than their Czech peers did.

Many research studies suggest that the presence (a $\mathrm{TV}$ or PC in the bedroom, watching TV with parents) or absence (limiting parental rules) of family environment factors might increase screen time among adolescents. These factors could subsequently be associated with poor eating habits (Garrison et al., 2011) or overweight (Beets at al., 2010). There are also several indices for increase in sleeping problems (Barr-Anderson et al., 2008), when TV (PC) is located in the children's bedroom. Parents therefore might have an available means to directly or indirectly affect the amount of time spent in front of the screen.

This study has several important strengths. The most important strength is the methodology of the international HBSC study used in our study, which has proved to be adaptable to developments in the research areas within and around public health and policy (Brindova, Pavelka, et al., 2014). For all surveys, a standardized research protocol providing a theoretical framework for the research topics and data collection and analysis procedures is developed (Roberts et al., 2009).
In addition, the regional Central European comparisons provide baseline data which could be useful for the future investigation of health-related behaviour.

On the other hand, the study also has some limitations. The main limitation is that we used only selfreported data. For example, some studies indicate that questionnaires were unable to assess screen time exactly, because children could be engaging in multiple activities at the same moment (e.g. watching TV while playing computer games). In connection with this, doubts might arise whether such activities should belong to one or another category or to both of them, which might then be reflected in the results (Bobakova et al., 2014; Corder et al., 2009). On the other hand, the accuracy of objective tools is dependent on the type of activity. Moreover, the usage of an objective tool (e.g. an accelerometer) is dependent on the adherence of respondents to wearing it or financial factors and the available manpower needed to process the data (Baquet, Stratton, Van Praagh, \& Berthoin, 2007; Nilsson, Ekelund, Yngve, \& Sjöström, 2002; Slootmaker, Schuit, Chinapaw, Seidell, \& Van Mechelen, 2009).

However, all these ways are standard in the measurement of screen-based behaviour. Second, the construction of sedentary behaviour items does not take into account the fact that children could be engaging in multiple activities at the same moment, e.g. watching TV while playing PC games. In connection with this, doubts might arise as to whether such activities should belong to one or the other category or to both of them, which might then be reflected in the results (Yang et al., 2012).

\section{Conclusions}

This study assessed country, age, and gender differences in the prevalence of sedentary screen-based activities and family-related factors among school-aged children in two countries. The data showed that the Czech Republic and Slovakia do not differ in any screen-based activity or family environment factors. Moreover, our study indicates that boys and girls do not differ in their screen-based behaviour, with the exception of PC use. Similarly, no differences are indicated in the application of parental rules. Our findings suggest that parents tend to restrict PC time more often for boys than girls. In terms of age, the time spent on screen-based activities increases with age among Czech and Slovak children. The same applies to parents restricting TV time and content. Using the computer decreases as children get older. 


\section{Acknowledgments}

This paper was supported by the Slovak Research and Development Agency under contract no. APVV-003211, by the Scientific Grant Agency of the Ministry of Education, Science, Research and Sport of the Slovak Republic and the Slovak Academy of Sciences, reg. no. $1 / 0895 / 14$, and by the Czech Ministry of Education, Youth and Sports under Contracts No. LG14042 and No. LG 14043.

\section{Conflict of interest}

There were no conflicts of interest.

\section{References}

American Academy of Pediatrics. (2001). Children, adolescents, and television. Pediatrics, 107, 423-426.

Atkin, A. J., Corder, K., \& van Sluijs, E. M. (2013). Bedroom media, sedentary time and screen-time in children: A longitudinal analysis. International Journal of Behavioral Nutrition and Physical Activity, 10, 137.

Baquet, G., Stratton, G., van Praagh, E., \& Berthoin, S. (2007). Improving physical activity assessment in prepubertal children with high frequency accelerometry monitoring: A methodological issue. Preventive Medicine, 44, 143-147.

Barr-Anderson, D. J., Van Den Berg, P., Neumark-Sztainer, D., \& Story, M. (2008). Characteristics associated with older adolescents who have a television in their bedrooms. Pediatrics, 121, 718-724.

Beets, M. W., Cardinal, B. J., \& Alderman, B. L. (2010). Parental social support and the physical activity-related behaviors of youth: A review. Health Education and Behavior, 37, 621-644.

Biddle, S. J. H., O’Connell, S., \& Braithwaite, R. E. (2011). Sedentary behaviour interventions in young people: A meta-analysis. British Journal of Sports Medicine, 45, 937-942.

Bobakova, D., Hamrik, Z., Badura, P., Sigmundova, D., Nalecz, H., \& Kalman, M. (2014). Test-retest reliability of selected physical activity and sedentary behaviour HBSC items in the Czech Republic, Slovakia and Poland. International Journal of Public Health, 60, 59-67.

Brindova, D., Pavelka, J., Sevcikova, A., Zezula, I., van Dijk, J., Reijneveld, S., \& Madarasova Geckova, A. (2014). How parents can affect excessive spending of time on screenbased activities. BMC Public Health, 14, 1261.

Brindova, D., Veselska, Z. D., Klein, D., Hamrik, Z., Sigmundova, D., van Dijk, ... Geckova, A. M. (2014). Is the association between screen-based behaviour and health complaints among adolescents moderated by physical activity? International Journal of Public Health, 60, 139-145.

Bucksch, J., Inchley, J., Hamrik, Z., Finne, E., \& Kolip, P. (2014). Trends in television time, non-gaming PC use and moderate-to-vigorous physical activity among German adolescents 2002-2010. BMC Public Health, 14, 351.

Canadian Pediatric Society. (1999). Children and the media. Paediatrics and Child Health, 4, 350-354.

Corder, K., van Sluijs, E. M., Wright, A., Whincup, P., Wareham, N. J., \& Ekelund, U. (2009). Is it possible to assess free living physical activity and energy expenditure in young people by self-report? American Journal of Clinical Nutrition, 89, 862-870.

De Decker, E., De Craemer, M., De Bourdeaudhuij, I., Wijndaele, K., \& Duvinage, K. (2013). Influencing factors of screen time in preschool children: An exploration of parents' perceptions through focus groups in six European countries. Obesity Reviews, 13(Suppl.), S75-S84.

Ekelund, U., Brage, S., Froberg, K., Harro, M., Anderssen, S. A., Sardinha, L. B., ... Andersen, L. B. (2006). TV viewing and physical activity are independently associated with metabolic risk in children: The European youth heart study. PLoS Medicine, 12, 2449-2457.

Garmendia, M., Garitaonandia, C., Martinez, G., \& Casado, M. A. (2012). The effectiveness of parental mediation. In S. Livingstone \& L. Haddon (Eds.), Children, risk and safety on the internet: Research and policy challenges in comparative perspective (pp. 231-244). Bristol, United Kingdom: The Policy Press.

Garrison, M. M., Liekweg, K., \& Christakis, D. A. (2011). Media use and child sleep: The impact of content, timing, and environment. Pediatrics, 128, 29-35.

Granich, J., Rosenberg, M., Knuiman, M., \& Timperio A. (2010). Understanding children's sedentary behaviour: A qualitative study of the family home environment. Health Education Research, 25, 199-210.

Guthold, R., Cowan, M. J., Autenrieth, C. S., Kann, L., \& Riley, L. M. (2010). Physical activity and sedentary behavior among schoolchildren: A 34-country comparison. Pediatrics, 157, 43-49.e1.

Hamar, P., Biddle, S., Soós, I., Takács, B., \& Huszár. A. (2009). The prevalence of sedentary behaviours and physical activity in Hungarian youth. European Journal of Public Health, 20, 85-90.

He, M., Harris, S., Piché, L., \& Beynon, C. (2009). Understanding screen-related sedentary behavior and its contributing factors among school-aged children: A social-ecological exploration. American Journal of Health Promotion, 23, 299-308.

Hersey, J. C., McDivitt, J. A., \& Heitzler, C. D. (2006). Reducing children's television-viewing time: A qualitative study of parents and their children. Pediatrics, 118, E1303-E1310.

Inchley, J., Currie, D., Young, T., Samdal, O., Torsheim, T., Augustson, L., ... Barnekow, V. (Eds.). (2016). Growing up unequal: Gender and socioeconomic differences in young people's health and well-being. Health Behaviour in Schoolaged Children (HBSC) study: International report from the 2013/2014 survey. Copenhagen, Denmark: WHO Regional Office for Europe. Retrieved from http://www.euro.who. int/__data/assets/pdf_file/0003/303438/HSBC-No7Growing-up-unequal-full-report.pdf?ua=1

Livingstone, S. M. (2011). Risk and safety on the internet: The perspective of European children. Full findings and policy implications from the EU Kids Online survey of 9-16 
year olds and their parents in 25 countries. London, United Kingdom: The London School of Economics and Political Science.

Livingstone, S., Haddon, L., Görzig, A., \& Ólafsson, K. (2011). Risks and safety on the internet: The perspective of European children. Full Findings. London, United Kingdom: EU Kids Online.

Loke, A., \& Mak, Y. W. (2013). Family process and peer influences on substance use by adolescents. International Journal of Environmental Research and Public Health, 10, 3868-3885.

Marshall, S. J., Gorely, T., \& Biddle, S. J. H. (2006). A descriptive epidemiology of screen-based media use in youth: A review and critique. Journal of Adolescence, 29, 333-349.

Melkevik, O., Torsheim, T., Iannotti, R., \& Wold, B. (2010). Is spending time in screen-based sedentary behaviors associated with less physical activity: A cross national investigation. International Journal of Behavioral Nutrition and Physical Activity, 7, 46.

Murray, J. P. (2008). Media violence: The effects are both real and strong. American Behavioral Scientist, 51, 1212-1230.

Nilsson, A., Ekelund, U., Yngve, A., \& Sjöström, M. (2002). Assessing physical activity among children with accelerometers using different time sampling intervals and placements. Pediatric Exercise Science, 14, 87-96.

Rebholz, C. E., Chinapaw, M. J. M., van Stralen, M. M., Bere, E., \& Bringolf, B. (2014). Agreement between parent and child report on parental practices regarding dietary, physical activity and sedentary behaviours: The ENERGY cross-sectional survey. BMC Public Health, 14, 918.

Rideout, V. J., Foehr, U. G., \& Roberts, D. F. (2010). GENERATION M²: Media in the lives of 8- to 18-year-olds. A Kaiser Family Foundation Study. Menlo Park, CA: The Henry J. Kaiser Family Foundation.

Roberts, C., Freeman, J., Samdal, O., Schnor, C., Looze, M., Gabhainn, S. N., \& Iannotti, R. (2009). The Health Behaviour in School-aged Children (HBSC) study: Methodological developments and current tensions. International Journal of Public Health, 54(Suppl. 2), 140-150.

Rosenberg, D. E., Sallis, J. F., Kerr, J., Maher, J., Norman, G. J., Durant, N. ... Saelens, B. E. (2010). Brief scales to assess physical activity and sedentary equipment in the home. International Journal of Behavioral Nutrition and Physical Activity, 7, 10.

Salmon, J., Timperio, A., Telford, A., Carver, A., \& Crawford, D. (2012). Association of family environment with children's television viewing and with low level of physical activity. Obesity Research, 13, 1939-1951.
Sigmundová, D., Sigmund, E., Kalman, M., \& Hamrik, Z. (2013). Trends of overweight and obesity, physical activity and sedentary behaviour in Czech schoolchildren: HBSC study. European Journal of Public Health, 24, 210-215.

Slootmaker, S. M., Schuit, A. J., Chinapaw, M. J. M., Seidell, J. C., \& van Mechelen, W. (2009). Disagreement in physical activity assessed by accelerometer and self-report in subgroups of age, gender, education and weight status. International Journal of Behavioral Nutrition and Physical Activity, 6, 17.

Soos, I., Biddle, S., Boros-Balint, I., Sandor, I., \& Szabo, P., Hamar, P., \& Simonek, J. (2012). Prevalence of sedentary behaviour in young people in Romania and Slovakia. European Physical Education Review, 18, 19-46.

Steinberg, L., \& Morris, A. S. (2001). Adolescent development. Annual Review of Psychology, 52, 83-110.

Strasburger, V. C., Jordan, A. B., \& Donnerstein, E. (2010). Health effects of media on children and adolescents. Pediatrics, 125, 756-767.

Sweeting, H., West, P., \& Richards, M. (1998). Teenage family life, lifestyles and live chances: Associations with family structure, conflict with parents and joint family activity. International Journal of Law, Policy and the Family, 12, $15-46$.

Tandon, P., Frank, L., Sallis, J., Zhou, C., Saelens, B., \& Cain, K. (2012). Home environment relationships with children's physical activity, sedentary time, and screen time by socioeconomic status. International Journal of Behavioral Nutrition and Physical Activity, 9, 88.

Te Velde, S. J., Van der Horst, K., Oenema, A., Timperio, A., Crawford, D., \& Brug, J. (2011). Parental and home influences on adolescents' TV viewing: A mediation analysis. International Journal of Pediatric Obesity, 6, e364-e372.

Torsheim, T., Eriksson, L., Schnohr, C. W., Hansen, F., Bjarnason, T., \& Valimaa, R. (2010). Screen-based activities and physical complaints among adolescents from the Nordic countries. BMC Public Health, 10, 324.

Valkenburg, P. M., Krcmar, M., Peeters, A. L., \& Marseille, N. M. (1999). Developing a scale to assess three styles of television mediation: "Instructive mediation", "restrictive mediation", and "social coviewing". Journal of Broadcasting and Electronic Media, 43, 52-66.

Vandewater, E. A., Park, S. E., Huang, X., \& Wartella, E. A. (2005). "No - You can't watch that": Parental rules and young children's media use. American Behavioral Scientist, 48, 608-623.

Yang, F., Helgason, A. R., Sigfusdottir, I. D., \& Kristjansson, A. L. (2012). Electronic screen use and mental well-being of 10-12 year old children. European Journal of Public Health, 23, 492-498. 